\title{
Uma Proposta para Regulamentação do Parágrafo Único do art. 23 da Constituição sob a Perspectiva Ambiental
}

Igor Tamasauskas'

\section{Introdução}

O art. 23 da Constituição Federal de 1988 elenca uma série de competências comuns à União, aos Estados, ao Distrito Federal e aos Municípios, desde a etérea "guarda da Constituição, das leis e das instituiçōes democráticas e conservar o patrimônio público", até a garantia de acesso à saúde, educação, cultura e ciência, passando pela proteção do meio ambiente, das florestas, da fauna e da flora, dos patrimônios históricos, artísticos e culturais, enfim aquelas descritas nos incisos do mencionado dispositivo. Tal gama de responsabilidades, muito amplas e diversas, por sinal, é cotidianamente desempenhada pelos entes federativos, nas mais básicas atividades administrativas.

Essas atribuiçōes encontram-se pormenorizadamente tratadas em capítulos específicos da Constituição, em detalhamento das ações a serem desempenhadas pelo Estado na preservação desses bens juridicamente protegidos. Assim, as atribuiçōes previstas no inciso I do art. 23 vêm minudenciadas no art. 37. dentre outros; a saúde e a assistência pública, estabelecidas no inciso II, encontram-se detalhadas nos arts. 198 e seguintes da Carta; ou, ainda, a educação, cujas minúcias descrevem-se nos arts. 205 e seguintes.

A despeito de citaçōes esparsas, dentre outros, no inciso VI do art. 170, da Carta, o meio ambiente é abordado num capítulo específico, composto pelo artigo 225, no qual tais competências são desdobradas em ações um tanto mais concretas, como se pode notar nos incisos do parágrafo primeiro. Entrementes, ao contrário, por exemplo, dos grandes temas saúde e educação, cujo detalhamento contempla uma melhor hierarquização ou orientação para repartição das ativida- 
des entre os entes federativos, os esforços para proteção das paisagens naturais notáveis, do meio ambiente, do combate à poluição em qualquer de suas formas e da preservação das florestas, da fauna e da flora, previstas no art. 23, incisos III, VI e VII, da Constituição, são cometidos indistintamente ao Poder Público em sentido amplo. Compete, portanto, a todos os Municípios, a todos os Estados, ao Distrito Federal e à União empenhar-se nas tarefas que tais.

Não nos parece, com isso, que o constituinte tenha desejado que a cada fato da vida, por mais singelo que fosse, correspondesse uma ação administrativa em cada uma das esferas da federação. Tal hipótese significaria um desnecessário desperdício de recursos públicos cuja energia deve ser otimizada e canalizada eficientemente para atender às mais diversas demandas por ações do Estado.

A solução que o legislador constituinte encontrou para resolver como deve ser a atuação dos entes federativos nas diversas competências comuns, como se pode facilmente ler do parágrafo único do art. 23, seria a edição de lei complementar, a fixar as normas de cooperação entre União, Estados, Distrito Federal e Municípios, com o objetivo maior de alcançar "o equilíbrio do desenvolvimento e do bem-estar em âmbito nacional". A simplicidade do dispositivo mencionado contrasta com a dificuldade de se imaginar qual o desenho que poderia ter tal norma complementar. Seria apenas uma norma descrevendo como se dariam convênios, consórcios, termos e acordos de parceria, típicos instrumentos de cooperação? Parece-nos que não, pois tais previsões abundam em nossa doutrina e legislação.

O desafio era como construir uma estrutura normativa que pudesse, em matéria do meio ambiente, definir, com clareza, como deve ser o relacionamento dos entes federativos para, sem perder de vista o objetivo maior de efetivamente proteger o conjunto de bens jurídicos descritos na Constituição, permitir uma atuação articulada e harmônica do Poder Público. Nessa seara, não se cogita de singela redistribuição das competências comuns previstas na Constituição, pela lei complementar; não, isso seria uma clara afronta ao texto maior, pois a lei, ainda que complementar, não poderia separar o que a Constituição uniu.

O verdadeiro objetivo era definir com clareza as normas de atuação (cooperação) de cada ente federativo, nas ações decorrentes do exercício das competências comuns, sem que isso implicasse na exclusão da atuação dos demais entes não diretamente envolvidos. Como se verá ao longo deste estudo, que orientou as discussões para a elaboração do projeto de lei complementar encaminhado sob a Mensagem $n^{\circ} 37$, espera ter-se minimamente alcançado tais objetivos.

\section{Competências em meio ambiente}

As competências dos entes federativos, previstas a partir do art. 21 da Constituição, decorrem do exercício da autonomia que lhes foi outorgada pelo legislador constituinte e orientam a atuação de cada esfera federativa nas atividades administrativa e normativa desempenhadas pelos seus órgãos e entidades. 
A doutrina ocupou-se em estabelecer classificações para essas competências. Para José Afonso da Silva, as competências constitucionais podem ser sistematizadas segundo (i) a forma, (ii) o conteúdo, (iii) a extensão e (iv) a origem, ${ }^{2}$ conforme os seguintes critérios: (i) seja prevista expressa ou residualmente prevista na Constituição; (ii) veicule matéria econômica, social, financeira ou tributária; (iii) outorgue competência a apenas um ente federativo exclusivamente, a mais de um, concorrentemente, ou a todos, indistintamente; e (iv) seja originária do texto maior ou decorrente de delegação. Barroso, ${ }^{3}$ de seu turno, as divide em três categorias: (a) político-administrativa; (b) legislativa; e (c) tributária. Ainda segundo o constitucionalista,

ao lado das competências político-administrativas exclusivas de cada entidade, bem como das competências legislativas privativas que se lhes deferiu, a nova Carta também previu competências político-administrativas comuns (art. 23); e competências legislativas concorrentes (art. 24).

Independentemente da classificação adotada, importam a esse estudo as competências administrativas comuns ou paralelas, estabelecidas no art. 23, e relativamente às quais a Carta outorgou indistintamente a todos os entes federativos a responsabilidade pela sua consecução. Tais competências são inderrogáveis justamente porque a Constituição as cometeu ao poder público sentido amplo. Cometeu as competências na área de meio ambiente a todos os entes federativos, mas não as ações específicas decorrentes das competências. Assim, proteger o meio ambiente, que é tarefa comum à Uniāo, aos Estados, ao Distrito Federal e aos Municípios, não se confunde com a tarefa administrativa concreta para se coibir o lançamento de efluentes não tratados num determinado curso d'água ou expedir licença para instalação de um dado empreendimento. Noutras palavras, a competência para a atuação ambiental não deve ser entendida como uma outorga geral e irrestrita para todos os entes federativos promoverem ações administrativas concretas em quaisquer hipóteses da vida. O reverso seria institucionalizar a balbúrdia federativa, em prejuízo da eficiência administrativa e da segurança jurídica que deve ser conferida ao cidadão, em geral, e ao empreendedor, em particular.

Importam-nos a este estudo as competências comuns porque a matéria ambiental encontra-se no rol de matérias cometidas à União, aos Estados, ao Distrito Federal e aos Municípios de maneira indeterminada no mencionado art. 23. Tal tratamento na Constituição parece ter decorrido da necessidade de se conferir ao tema o mais amplo arco de proteção ao bem jurídico meio ambiente ecologicamente equilibrado, ao legitimar todos os entes da federação para efetivamente agir em sua defesa. Uma ofensa, ou ameaça, a esse bem pode - e deve - ser obstada por qualquer dos entes federativos, pois a reparação a um dano ambiental, por mais ampla que venha a ser, pode não significar o retorno ao status quo ante. Assim,

2 Curso de direito constitucional. 22. ed. São Paulo: Malheiros, 2003.

3 Arquivos do Ministério da Justiça, 45 (179): 47-80, jan./jun. 1992. 
a vulneração do habitat de uma espécie ameaçada ou a contaminação do lençol freático podem não ser reversíveis, por mais sofisticadas e caras que sejam as técnicas aplicadas. Não significa, porém, que estamos condenados a não realizar os empreendimentos e as atividades necessários ao desenvolvimento do país; o que a Constituição determina claramente é que esse desenvolvimento se faça respeitante aos mandamentos de proteção ambiental, ou seja, que o desenvolvimento seja ecologicamente sustentável.

Essa preocupação da Constituição, no mais das vezes, aliada à não-regulamentaçāo do parágrafo único do art. 23 , tem trazido inúmeros problemas de ordem prática na definição das competências administrativas de cada ente federativo quando se deparam com um fato determinado. A quem compete licenciar a usina hidrelétrica tal? E fiscalizar a empresa com intensiva dispensa de efluentes? Autorizar a supressão de vegetação em área de proteção ambiental? Atualmente essas definições constam da Lei $n^{\circ}$ 6.938/81, Lei da Política Nacional do Meio Ambiente, editada anteriormente à Constituição atual que, como se sabe, alçou os Municípios à condição de integrantes autônomos da federação, além de Resoluçōes do Conselho Nacional do Meio Ambiente, CONAMA, com destaque para a Resolução nº 237/97.

Todos esses pontos permearam as discussões durante a elaboração do projeto de lei complementar que ora está sob consideração do Congresso Nacional. A saída encontrada foi estabelecer critérios de atuação que estivessem em conformidade com aquela estabelecida pela Constituição para a própria repartição das competências exclusivas dos entes federativos, sem perder de vista que remanescem aos demais entes competências para auxiliar aquele a quem estiver cometida determinada atuação. Assim, competirá à União as ações administrativas de interesse nacional ou federal, aos Municípios, as de ordem local, e aos Estados aquilo que não estiver afeto ao interesse estritamente local ou esteja cometido à União. $\mathrm{E}$, ao ente que não estiver diretamente envolvido na ação administrativa específica, competirá prestar auxílio técnico, científico, administrativo ou financeiro.

Buscou-se, com isso, conciliar o critério de predominância de interesse na definição de ações administrativas - e não competências constitucionais - com a previsibilidade de atuação subsidiária do ente federativo não diretamente envolvido na ação protetiva. Subsidiária, entenda-se, no sentido de prestar auxílio, colaboração ou cooperação ao ente federativo a quem a proposta de lei complementar determinou a prática da ação administrativa concreta. E, na hipótese de inexistência do órgão ambiental estadual ou municipal, subsidiária como assunção provisória de suas responsabilidades pelos órgãos federal ou estadual.

Ao fim e ao cabo, o projeto de lei complementar visa à unificação da política de proteção ao meio ambiente, na forma autorizada e estimulada pelo parágrafo único do art. 23 da Constituiçāo, com a finalidade de integrar as ações dos diversos órgãos e entidades da Administração Pública de maneira harmônica, eficiente e democrática. 


\section{O projeto de lei complementar}

Passadas as considerações iniciais, é importante apresentar o projeto de lei complementar, na forma como encaminhada pelo Poder Executivo à consideração do Congresso Nacional.

A proposta está estruturada em três capítulos, a saber: capítulo I, com as disposições preliminares; capítulo II, veiculando os instrumentos possíveis de cooperação ambiental; e capítulo III, que traz as açōes de cooperação propriamente ditas, especificando o papel de cada ente federativo relativamente ao conjunto de responsabilidades ambientais previstas na Constituição.

$\mathrm{O}$ art. $1^{\circ}$ da proposta define o seu objeto, qual seja, e por óbvio, fixar normas para a cooperação entre a União, os Estados, o Distrito Federal e os Municípios, nas açōes administrativas decorrentes do exercício da competência comum relativa à proteção das paisagens naturais notáveis, à proteção do meio ambiente, ao combate à poluição em qualquer de suas formas e à preservação das florestas, da fauna e da flora, previstas no art. 23, incisos III, VI e VII, da Constituição Federal. Diante da exaustividade do dispositivo, bem como da auto-explicação que nele se contém, não há necessidade de aprofundamento para os fins desse estudo.

Em seqüência, o art. $2^{\circ}$ traça os objetivos fundamentais a serem atingidos com a aplicação da lei complementar que vier a ser aprovada pelo Congresso Nacional, reservados os dois primeiros incisos para a proteção ambiental propriamente dita e os três incisos seguintes para a atuação dos entes federativos. Procurou-se garantir a não sobreposição de atuação dos entes como um dos objetivos principais do projeto, calçado, inclusive, em interessante precedente do Supremo Tribunal Federal, ${ }^{4}$ assim ementado:

Federação - competência comum - proteção do patrimônio comum, incluído o dos sítios de valor arqueológico (CF, arts. 23, III, e 216, V) - encargo que não comporta demissão unilateral.

1. L. est. 11.380, de 1999, do Estado do Rio Grande do Sul, confere aos municípios em que se localizam a proteção, a guarda e a responsabilidade pelos sítios arqueológicos $e$ seus acervos, no Estado, o que vale por excluir, a propósito de tais bens do patrimônio cultural brasileiro ( $C F$, art. 216, V), o dever de proteção e guarda e a conseqüente responsabilidade não apenas do Estado, mas também da própria União, incluídas na competência comum dos entes da Federação, que substantiva incumbência de natureza qualificadamente irrenunciável.

2. A inclusão de determinada função administrativa no âmbito da competência comum não impõe que cada tarefa compreendida no seu domínio, por menos expressiva que seja, haja de ser objeto de ações simultâneas das três entidades federativas: donde, a previsão, no parágrafo único do art. $23 \mathrm{CF}$, de lei complementar que fixe normas

\footnotetext{
4 Ação Direta de Inconstitucionalidade n 2.544-9/RS - Rel. Min. Sepúlveda Pertence, publicada em 17.11.2006.
} 
de cooperação (v. sobre monumentos arqueológicos e pré-históricos, a L. 3.924/61), cuja edição, porém, é da competência da União e, de qualquer modo, não abrange o poder de demitirem-se a União ou os Estados dos encargos constitucionais de proteção dos bens de valor arqueológico para descarregá-los ilimitadamente sobre os Municípios.

3. Ação direta de inconstitucionalidade julgada procedente.

O precedente do Supremo Tribunal Federal, repercutindo posiçōes doutrinárias, pôde indicar dois verdadeiros princípios a auxiliar a edição de uma lei complementar como a discutida neste estudo: a irrenunciabilidade do exercício de uma competência comum e a não sobreposição de atuações dos entes federativos. Como se verá ao longo da exposição, essas observaçōes se expressam em diversas passagens.

Como síntese do que foi dito no parágrafo anterior, o art. $3^{\circ}$ da proposta insere o critério que foi utilizado para a repartição das açōes (ou tarefas) administrativas a serem adotadas pelos entes federativos no exercício das competências ambientais comuns: a predominância do interesse na proteção ambiental. Já foi mencionado alhures que os entes federativos deverão ter asseguradas suas atuações consoante a sua vocação, extraída da Constituição. Os Municípios devem se ocupar de questōes de interesse meramente local - v. g., corte de árvore em área efetivamente urbanizada, licenciamento ambiental de uma padaria. A União, de seu turno, deve se ocupar de questões cujo interesse nacional sobressaia, como, por exemplo, no licenciamento de empreendimentos cujo impacto ambiental seja sentido no território nacional, ou que extravasem os limites territoriais de mais de um Estado. Por fim, aos Estados competirá atender aos interesses intestinos às suas fronteiras e que ultrapassem os limites territoriais de um Município.

O parágrafo único deste dispositivo, como não poderia deixar de ser, prevê a inafastabilidade da atuação dos demais entes federativos, em cada ação específica, cuja característica, contudo, será a da subsidiariedade. Subsidiariedade, conforme acima mencionado, no sentido etimológico de auxílio, mas também no de substituição provisória, em caso de inexistência de órgão ambiental. Essa previsão decorre da irrenunciabilidade das competências previstas no art. 23 da Constituição. E também decorre da necessidade de se conferir um tratamento harmônico à questão, na forma da parte final do parágrafo único do mesmo art. 23. Esse tema será abordado novamente ao longo da exposição. Com esse dispositivo, encerra-se o primeiro capítulo da proposta.

O capítulo seguinte trata dos instrumentos de cooperação passíveis de utilizaçāo pelos entes federatives para o cumprimento das competências constitucionais em matéria de meio ambiente, a saber: (i) conselhos de meio ambiente; (ii) consórcios públicos e convênios de cooperação, nos termos da Lei nº 11.107/05; (iii) convênios e acordos de cooperação técnica e outros instrumentos similares; e (iv) fundos de meio ambiente. Tais instrumentos são amplamente conhecidos em nossa legislação, sendo objeto de intenso estudo doutrinário e jurisprudencial, razão pela qual se deixa de abordá-los com delongas. Contudo, inova-se na 
possibilidade de firmarem-se convênios com prazo indeterminado, sempre que seu objeto estiver em conformidade com as previsōes da proposta, quais sejam, instrumentalizar as açōes de cooperação ambiental entre órgãos e entidades do poder público.

Depois de estabelecidos os instrumentos pelos quais se dará a cooperação dos entes federativos, o projeto de lei complementar aborda as ações administrativas decorrentes do exercício das competências constitucionais. O capítulo III é aberto pelo art. $5^{\circ}$, cuja redação reforça a necessidade de harmonização das políticas nacional, estaduais e municipais de meio ambiente.

A seguir, o projeto apresenta três artigos, subdivididos em diversos incisos, que trazem, em rol não exaustivo, as principais ações administrativas da União, dos Estados e do Distrito Federal, e dos Municípios para que a harmonização preconizada no art. $5^{\circ}$ possa se materializar.

O art. $6^{\circ}$ trata das açōes administrativas cuja execução fica a cargo da União, quais sejam:

I - formular, executar e fazer cumprir, no nível nacional, a Política Nacional do Meio Ambiente;

II - exercer a gestão dos recursos ambientais, no âmbito de sua competência;

III - promover ações relacionadas à Política Nacional do Meio Ambiente, nos âmbitos nacional e internacional;

$I V$ - promover a integração de programas e ą̧ões de órgãos e entidades da Administração Pública da União, dos Estados, do Distrito Federal e dos Municípios, relacionados à proteção e à gestão do meio ambiente;

$V$ - articular a cooperação técnica, científica e financeira, em apoio à Política Nacional do Meio Ambiente;

$V I$ - promover o desenvolvimento de estudos e pesquisas direcionados à proteção e à gestão ambiental, divulgando os resultados obtidos;

VII - promover a articulação da Política Nacional do Meio Ambiente com a de Recursos Hídricos;

VIII - organizar e manter, com a colaboração dos órgãos e entidades da Administração Pública dos Estados, do Distrito Federal e dos Municípios, o Sistema Nacional de Informaçōes sobre o Meio Ambiente - SINIMA;

$I X$ - elaborar o zoneamento ambiental de âmbito nacional e regional;

$X$ - definir espaços territoriais e seus componentes a serem especialmente protegidos;

$X I$ - promover e orientar a educação ambiental;

$X I I$ - controlar a produção, a comercialização e o emprego de técnicas, métodos e substâncias que comportem risco para a vida, a qualidade de vida e o meio ambiente; 
$X I I I$ - exercer o controle e a fiscalização das atividades e empreendimentos cuja competência para licenciar, ambientalmente, for cometida à União;

$X I V$-exercer o controle e a fiscalização das atividades e empreendimentos cuja competência para autorizar, ambientalmente, for cometida à União;

$X V$ - promover o licenciamento ambiental das atividades ou empreendimentos, a saber:

a) que causem ou possam causar impacto ambiental direto de âmbito nacional ou regional;

b) localizados ou desenvolvidas conjuntamente no Brasil e em país limitrofe;

c) localizados na plataforma continental, na zona econômica exclusiva, em terras indígenas ou em unidades de conservação da União, exceto em Áreas de Proteção Ambiental - APAs, onde deverá ser observado o critério do impacto ambiental direto das atividades ou empreendimentos;

d) destinados a pesquisar, lavrar, produzir, beneficiar, transportar, armazenar e dispor material radioativo, em qualquer estágio, ou que utilizem energia nuclear em qualquer de suas formas e aplicações, mediante parecer da Comissão Nacional de Energia Nuclear - CNEN; $e$

e) empreendimentos e atividades militares que servem a defesa nacional, na forma da Lei;

XVI - elaborar a relação de espécies raras ou ameaçadas de extinção, da fauna e da flora, no território nacional;

XVII - autorizar a introdução no País de espécies exóticas da fauna e da flora;

XVIII - autorizar a liberação de exemplares de espécie exótica da fauna e da flora em ecossistemas naturais;

$X I X$ - autorizar a exportação de espécimes da flora e fauna brasileiras, partes ou produtos deles derivados; $e$

$X X$ - autorizar a supressão de vegetação e o manejo de florestas e de formações sucessoras em florestas públicas $e$ unidades de conservação da União, bem como em empreendimentos potencialmente causadores de impacto ambiental nacional ou regional, observadas as atribuições dos demais entes federativos previstas nesta Lei Complementar.

Dessas atribuições cometidas à Uniāo, as previstas nos incisos I, II, IV, V, VI, VIII a XV e XX são repetidas, nas previsões dos arts. $7^{\circ}$, para Estados e Distrito Federal, e $8^{\circ}$, para os Municípios, adaptando-se o necessário segundo o critério do interesse predominante na proteção ambiental. Buscou-se respeitar as regras já estabelecidas para os entes federativos nas normas atualmente em vigência $\mathrm{e}$ que, embora não estabeleçam regras para a cooperação dos entes federativos nessa matéria, tratem de normas gerais ambientais, como a Lei nº 6.938/81. 
Especial atenção deve ser conferida ao tema do licenciamento ambiental, tratado nos incisos XV do art. 6º XIV do art. $7^{\circ}$ e XIV do art. 8o, assim como nos arts. $9^{\circ}$ e 10 , todos do projeto de lei complementar. Esse tema vem suscitando inúmeros conflitos judiciais, dentre outras razôes, porque a Lei $n^{\circ} 6.938 / 81$, previu em seu art. $10^{5}$ que o licenciamento ambiental deve ser implementado pelo órgão estadual do meio ambiente e, em caráter supletivo, pelo Instituto Brasileiro do Meio Ambiente e Recursos Naturais Renováveis (IBAMA):

Art. 10. A construção, instalação, ampliação e funcionamento de estabelecimentos e atividades utilizadoras de recursos ambientais, considerados efetiva e potencialmente poluidores, bem como os capazes, sob qualquer forma, de causar degradação ambiental, dependerão de prévio licenciamento de órgão estadual competente, integrante do Sistema Nacional do Meio Ambiente - SISNAMA, e do Instituto Brasileiro do Meio Ambiente e Recursos Naturais Renováveis - IBAMA, em caráter supletivo, sem prejuízo de outras licenças exigiveis.

[...]

$\$ 4^{\circ}$ Compete ao Instituto Brasileiro do Meio Ambiente e Recursos Naturais Renováveis - IBAMA o licenciamento previsto no caput deste artigo, no caso de atividades e obras com significativo impacto ambiental, de âmbito nacional ou regional.

A Resolução CONAMA n² 237/97, de seu turno, previu a repartição das responsabilidades pelo licenciamento ambiental à União, aos Estados e Distrito Federal e aos Municípios, nos arts. $4^{\circ}$ a $6^{\circ}$, conforme critérios mistos, ora relativamente ao impacto ambiental, ora em relação à localização do empreendimento, ora em relação à sua natureza. A referida resolução, entretanto, vem sendo questionada judicialmente, dentre outras razões, por se tratar de norma infralegal, que, ademais, contraria a Lei $\mathrm{n}^{\mathrm{0}} 6.938 / 81$, ao prever a possibilidade de licenciamento procedido por órgão ambiental municipal.

Assim, a proposta de lei complementar contempla alguns avanços da Resolução CONAMA nº 237/97, como por exemplo, a unicidade do licenciamento ambiental perante o ente federativo cujo interesse de proteção ambiental for predominante, nos termos prescritos pelo projeto. Avança, nesse ponto, ao facultar, sempre, a manifestação dos demais entes federativos interessados, mas sem vincular a concessão da licença a essa manifestação. Por óbvio que o ente concessor da licença deverá, na hipótese de discordância, fundamentar suas razōes e motivos. Por fim, avança, ainda, na previsão do $\$ 2^{\circ}$ do art. $9^{\circ}$, que determina ser de responsabilidade do ente licenciador autorizar a supressão de vegetação decorrente do empreendimento ou atividade licenciados.

Restam evidenciados, ainda, os critérios para a definiçâo do ente licenciador.

5 Redaçāo dada pela Lei $n^{\mathrm{o}}$ 7.804/89. 
A União responderá pela concessão de licença ambiental de empreendimentos ou atividades que (a) que causem ou possam causar impacto ambiental direto de âmbito nacional ou regional; (b) localizados ou desenvolvidas conjuntamente no Brasil e em país limítrofe; (c) localizados na plataforma continental, na zona econômica exclusiva, em terras indígenas ou em unidades de conservação da União, exceto em Áreas de Proteção Ambiental (APAs) onde deverá ser observado o critério do impacto ambiental direto das atividades ou empreendimentos; (d) destinados a pesquisar, lavrar, produzir, beneficiar, transportar, armazenar e dispor material radioativo, em qualquer estágio, ou que utilizem energia nuclear em qualquer de suas formas e aplicações, mediante parecer da Comissão Nacional de Energia Nuclear (CNEN) ou (e) empreendimentos e atividades militares que servem a defesa nacional, na forma da Lei. Claramente adotando o critério misto para a definição de responsável pelo licenciamento, portanto.

Os Estados e o Distrito Federal deverāo licenciar aqueles que (a) causem ou possam causar impacto ambiental direto de âmbito estadual; ou (b) estejam localizados em unidades de conservação do Estado ou do Distrito Federal, exceto em Áreas de Proteção Ambiental (APAs), onde deverá ser observado o critério do impacto ambiental direto das atividades ou empreendimentos.

De seu turno, os Municípios responderão pelas licenças (a) que causem ou possam causar impacto ambiental direto de âmbito local; ou (b) localizados em unidades de conservação do Município, exceto em Áreas de Proteção Ambiental (APAs), onde deverá ser observado o critério do impacto ambiental direto das atividades ou empreendimentos.

$\mathrm{O}$ art. 10 da proposta busca definir os conceitos de impacto ambiental segundo a abrangência, considerando-se impacto ambiental direto de âmbito nacional ou regional: aquele que afete diretamente, no todo ou em parte, o território de dois ou mais Estados Federados ou cujos impactos ambientais significativos diretos ultrapassem os limites territoriais do País (inciso I); impacto ambiental direto de âmbito estadual: aquele que afete diretamente, no todo ou em parte, o território de dois ou mais Municípios (inciso II); e impacto ambiental direto de âmbito local: aquele que afete diretamente, no todo ou em parte, o território de um Município sem ultrapassar o seu limite territorial (inciso III).

Muito se debateu acerca desses critérios, que poderiam ser mais objetivos, ou sugerindo veicularem rol exaustivo, ou, ainda, que a União poderia atribuir a responsabilidade pelo licenciamento ambiental em cada hipótese. Propôs-se, ainda, a utilização de critérios outros, como a dominialidade ${ }^{6}$ do bem em que se desenvolverá o empreendimento ou a sua territorialidade. Nenhuma dessas pro-

\footnotetext{
6 O projeto de lei complementar utiliza o critério de dominialidade em algumas hipóteses, quais sejam, aqueles localizados na plataforma continental, na zona econômica exclusiva, em terras indígenas ou em unidades de conservação da União, exceto em Áreas de Protę̧ão Ambiental (APAs), onde deverá ser observado o critério do impacto ambiental direto das atividades ou empreendimentos (art. $6^{\circ}, \mathrm{XV}, c$ ).
} 
postas logrou afastar aquela adotada pelo projeto de lei complementar, posto que, falhas em muitos aspectos.

Quanto à objetividade dos critérios, a definição colide com a multiplicidade de características encontradas em todo o território nacional; tampouco os críticos dessa escolha puderam construir uma alternativa mais definida. Os critérios de impacto, ademais, são amplamente conhecidos atualmente, por força da Lei $\mathbf{n}^{\circ}$ 6.938/81 e da Res. CONAMA no 237/97, e encontram respaldo constitucional. A lógica do projeto de lei complementar foi embasada na inderrogabilidade da defesa do meio ambiente por União, Estados, Distrito Federal e Municípios, sem prevalência de qualquer dos entes federados, consoante a dicção do art. $1^{\circ}$ da Carta. Nada mais natural, portanto, que a ação dos entes se paute pelo impacto da atividade sobre o bem jurídico protegido e não pelos critérios acima sugeridos.

Assim, prever-se um rol exaustivo de atividades licenciadas pela União, outro para os Estados e Distrito Federal e um terceiro para os Municípios traria as dificuldades que normalmente acompanham tal opção legislativa: como estaria amparada uma atividade que não se encontrasse no rol? Tampouco poderia uma lei complementar de harmonização federativa entrar em tais minúcias de licenciamento, cuja atribuição parece mais afeta a uma lei geral de licenciamentos, categoria em que se enquadraria a Lei $n^{\circ} 6.938 / 81$, na parte em que trata do tema. Ademais, o avanço tecnológico imporia contínuas modificaçōes numa lei que previsse tal rol.

De outro lado, possibilitar à União a definição do ente responsável pelo licenciamento contraria as disposições constitucionais acerca do meio ambiente. Em nenhuma passagem, a União detém a atribuição de definir, em casos concretos, a responsabilidade pela atuação dos demais entes federativos. Ao contrário, por exemplo, na área de saúde, há previsão expressa de rede hierarquizada de atendimento. $\mathrm{Na}$ área ambiental, as competências são comuns e cometidas indistintamente a todos os entes federativos; não se pode imaginar uma norma que privilegie a cooperação, nos termos do parágrafo único do art. 23 , veicular norma que outorgue à União o poder de definir a atuação dos Estados, do Distrito Federal ou dos Municípios, como se esses fossem meras repartiçōes administrativas dela própria.

O critério de dominialidade pura, ou seja, responde pelo licenciamento o ente titular do bem onde se erigirá o empreendimento, tampouco se presta para resolver adequadamente o problema proposto. Por exemplo, nos terrenos de marinha e nos rios federais, a competência para outorgar licenciamentos seria da União, em qualquer hipótese e para qualquer relevância de empreendimento. Quebrar-se-ia a lógica constitucional de repartição de competências, ao reservar para Uniāo as tarefas afetas às questōes nacionais. Assim, num caso hipotético, empreendimentos idênticos, de potencial poluidor reduzido, seriam licenciados ou pelo Município ou pela União, a depender exclusivamente de sua localização. Noutra conjectura, havendo disputa pela dominialidade do bem afetado, restaria igualmente prejudicada a objetividade do critério.

Por fim, os três dispositivos seguintes do projeto de lei complementar visam a conferir a amarração final em matéria de cooperação, ao prever a atuação sub- 
sidiária dos entes federativos (art. 11), ao tratar das hipóteses de inexistência de órgāo ambiental organizado (art. 12), e ao dispor sobre medidas emergenciais para impedir ou cessar dano ambiental (art. 13).

Como se disse ao longo deste estudo, a atuação subsidiária dos demais entes federativos pode ser entendida como auxiliar ou supletiva.

No primeiro caso, o art. 11 da proposta contempla a participação auxiliar dos demais entes federativos não diretamente responsáveis por dada ação administrativa concreta. Sem perder de vista que se trata de competências constitucionais comuns, portanto inderrogáveis, o projeto de lei complementar em análise previu a possibilidade de prestação de apoio técnico, científico, administrativo ou financeiro, conforme a hipótese concretamente abordada.

Por conseguinte, o art. 12 disciplina a assunção das atividades relacionadas à proteção ambiental, pela União, na falta de Estados ou do Distrito Federal, e dos Estados, caso o Município não tenha estrutura ambiental devidamente organizada. Essa atuação supletiva se dará até que tais órgāos se estruturem na forma da legislação em vigor (Lei n⿳o 6.938/81 - Lei da Política Nacional do Meio Ambiente).

$\mathrm{O}$ art. 13 reforça o objetivo de nāo se sobreporem atuaçōes de entes federativos, ao determinar que uma lesão ambiental, ou ameaça de lesão, sejam imediatamente obstadas por qualquer órgão ambiental. Tomadas as providências de urgência - dentre outras, embargo de atividade - a questão deverá ser remetida para o ente responsável, na forma do projeto de lei complementar, para cuidar das medidas decorrentes, como instauração de procedimento administrativo que confirmará, ou nāo, o embargo, imporá penalidades, enfim, seguindo-se a tramitação perante o órgão a quem foram cometidas as atribuições, nos termos da proposta de lei complementar.

\section{PROJETO DE LEI COMPLEMENTAR ${ }^{7}$}

Fixa normas para a cooperação entre a União, os Estados, o Distrito Federal e os Municípios, nas ações administrativas decorrentes do exercício da competência comum relativas à proteção das paisagens naturais notáveis, à proteção do meio ambiente, ao combate à poluição em qualquer de suas formas e à preservação das florestas, da fauna e da flora, previstas no art. 23, incisos III, VI e VII, da Constituição.

\section{O CONGRESSO NACIONAL decreta:}

\footnotetext{
Este projeto de lei foi apresentado em plenário no dia 24 de janeiro de 2007 (PLP 388/2007). Atualmente, o projeto encontra-se na Comissāo de Agricultura, Pecuária, Abastecimento e Desenvolvimento Rural (CAPADR).
} 


\section{Capítulo I \\ Das Disposições Preliminares}

Art. $1^{\circ}$ Esta Lei Complementar fixa, nos termos do parágrafo único do art. 23 da Constituição, normas para a cooperação entre a Uniāo, os Estados, o Distrito Federal e os Municípios, nas ações administrativas decorrentes do exercício da competência comum relativa à proteção das paisagens naturais notáveis, à proteção do meio ambiente, ao combate à poluição em qualquer de suas formas e à preservação das florestas, da fauna e da flora, previstas no art. 23, incisos III, VI e VII, da Constituição Federal.

Art. $2^{\circ}$ Constituem objetivos fundamentais da União, dos Estados, do Distrito Federal e dos Municípios, no exercício da competência comum a que se refere esta Lei Complementar:

I - proteger, defender e preservar o meio ambiente ecologicamente equilibrado;

II - garantir o desenvolvimento ecologicamente sustentável;

III - harmonizar as ações administrativas para evitar a sobreposição de atuação dos entes federativos;

IV - garantir a unicidade da política ambiental para todo o país, respeitadas as peculiaridades regionais e locais; $\mathrm{e}$

$\mathrm{V}$ - promover a gestâo compartilhada, democrática e eficiente.

Art. $3^{2}$ As ações administrativas decorrentes da competência comum de que trata esta Lei Complementar deverão observar o critério da predominância do interesse nacional, regional e local na proteção ambiental.

Parágrafo único. O disposto no caput não afasta a atuação subsidiária dos demais entes federativos, de acordo com o disposto nesta Lei Complementar.

\section{Capítulo II \\ Dos Instrumentos de Coooperação}

Art. $4^{\circ}$ Os entes federativos poderão valer-se dos seguintes instrumentos com vistas ao compartilhamento das atividades previstas nesta Lei Complementar:

I - Conselhos de Meio Ambiente;

II - consórcios públicos ou convênios de cooperação, nos termos da legislação em vigor, para o exercício das competências fixadas nesta Lei Complementar;

III - convênios, acordos de cooperação técnica e outros instrumentos similares com órgãos e entidades do Poder Público, para auxiliar no desempenho de suas atribuiçōes; $\mathrm{e}$

IV - Fundos de Meio Ambiente. 
Parágrafo único. Os instrumentos mencionados no inciso III poderão ser firmados com prazo indeterminado.

\section{Capitulo III \\ Das Açōes de Cooperação}

Art. $5^{\circ}$ As ações de cooperação entre a União, os Estados, o Distrito Federal e os Municípios serão desenvolvidas de modo a harmonizar as políticas governamentais setoriais com a política nacional do meio ambiente.

Art. $6^{\circ}$ Para os fins do art. $5^{\circ}$, são ações administrativas da União, dentre outras:

I - formular, executar e fazer cumprir, no nível nacional, a Política Nacional do Meio Ambiente;

II - exercer a gestão dos recursos ambientais, no âmbito de sua competência;

III - promover ações relacionadas à Política Nacional do Meio Ambiente, nos âmbitos nacional e internacional;

IV - promover a integração de programas e ações de órgãos e entidades da Administração Pública da União, dos Estados, do Distrito Federal e dos Municípios, relacionados à proteção e à gestão do meio ambiente;

$\mathrm{V}$ - articular a cooperação técnica, científica e financeira, em apoio à Política Nacional do Meio Ambiente;

VI - promover o desenvolvimento de estudos e pesquisas direcionados à proteção e à gestão ambiental, divulgando os resultados obtidos;

VII - promover a articulação da Política Nacional do Meio Ambiente com a de Recursos Hídricos;

VIII - organizar e manter, com a colaboração dos órgãos e entidades da Administração Pública dos Estados, do Distrito Federal e dos Municípios, o Sistema Nacional de Informações sobre o Meio Ambiente - SINIMA;

IX - elaborar o zoneamento ambiental de âmbito nacional e regional;

$\mathrm{X}$ - definir espaços territoriais e seus componentes a serem especialmente protegidos;

XI - promover e orientar a educação ambiental;

XII - controlar a produção, a comercialização e o emprego de técnicas, métodos e substâncias que comportem risco para a vida, a qualidade de vida e o meio ambiente;

XIII - exercer o controle e a fiscalização das atividades e empreendimentos cuja competência para licenciar, ambientalmente, for cometida à União; 
XIV - exercer o controle e a fiscalização das atividades e empreendimentos cuja competência para autorizar, ambientalmente, for cometida à União;

$\mathrm{XV}$ - promover o licenciamento ambiental das atividades ou empreendimentos, a saber:

a) que causem ou possam causar impacto ambiental direto de âmbito nacional ou regional;

b) localizados ou desenvolvidas conjuntamente no Brasil e em país limítrofe;

c) localizados na plataforma continental, na zona econômica exclusiva, em terras indígenas ou em unidades de conservaçāo da Uniāo, exceto em Áreas de Proteção Ambiental (APAs), onde deverá ser observado o critério do impacto ambiental direto das atividades ou empreendimentos;

d) destinados a pesquisar, lavrar, produzir, beneficiar, transportar, armazenar e dispor material radioativo, em qualquer estágio, ou que utilizem energia nuclear em qualquer de suas formas e aplicaçōes, mediante parecer da Comissão Nacional de Energia Nuclear - CNEN; e

e) empreendimentos e atividades militares que servem a defesa nacional, na forma da Lei;

XVI - elaborar a relação de espécies raras ou ameaçadas de extinção, da fauna e da flora, no território nacional;

XVII - autorizar a introdução no País de espécies exóticas da fauna e da flora;

XVIII - autorizar a liberação de exemplares de espécie exótica da fauna e da flora em ecossistemas naturais;

XIX - autorizar a exportação de espécimes da flora e fauna brasileiras, partes ou produtos deles derivados; $\mathrm{e}$

$\mathrm{XX}$ - autorizar a supressão de vegetação e o manejo de florestas e de formações sucessoras em florestas públicas e unidades de conservação da União, bem como em empreendimentos potencialmente causadores de impacto ambiental nacional ou regional, observadas as atribuições dos demais entes federativos previstas nesta Lei Complementar.

Art. $7^{0}$ Para os fins do art. 50, são ações administrativas dos Estados e do Distrito Federal, dentre outras:

I - executar e fazer cumprir, no nível estadual, a Política Nacional de Meio Ambiente;

II - exercer a gestão dos recursos ambientais do âmbito de sua competência estadual;

III - formular, executar e fazer cumprir, no nível estadual, a Política Estadual de Meio Ambiente; 
IV - promover, no âmbito estadual e distrital, a integração de programas e açōes dos órgãos e entidades da Administração Pública da União, dos Estados, do Distrito Federal e dos Municípios, relacionados à proteção e à gestāo ambiental;

$\mathrm{V}$ - articular a cooperação técnica, científica e financeira, em apoio às Políticas Nacional e Estadual de Meio Ambiente;

VI - promover o desenvolvimento de estudos e pesquisas direcionados à proteção e à gestão ambiental, divulgando os resultados obtidos;

VII - organizar e manter, com a colaboração dos órgãos municipais competentes, o Sistema Estadual de Informações sobre Meio Ambiente;

VIII - prestar informações à União para a formação e atualização do Sistema Nacional de Informaçōes sobre Meio Ambiente;

IX - elaborar o zoneamento ambiental de âmbito estadual ou distrital, em conformidade com o zoneamento nacional;

$\mathrm{X}$ - definir espaços territoriais e seus componentes a serem especialmente protegidos;

XI - promover e orientar a educação ambiental em todos os níveis de ensino e a conscientização pública para a proteção do meio ambiente;

XII - exercer o controle e a fiscalização das atividades e empreendimentos cuja competência para licenciar, ambientalmente, for cometida aos Estados ou ao Distrito Federal;

XIII - exercer o controle e a fiscalização das atividades e empreendimentos cuja competência para autorizar, ambientalmente, for cometida aos Estados ou ao Distrito Federal;

XIV - promover o licenciamento ambiental das atividades ou empreendimentos, a saber:

a) que causem ou possam causar impacto ambiental direto de âmbito estadual; e

b) localizados em unidades de conservação do Estado ou do Distrito Federal, exceto em Áreas de Proteção Ambiental - APAs, onde deverá ser observado o critério do impacto ambiental direto das atividades ou empreendimentos;

XV - autorizar a supressão de vegetação e o manejo de florestas e de formações sucessoras incidentes em florestas públicas e unidades de conservação do Estado e do Distrito Federal, bem como em propriedades rurais, observadas as atribuiçōes dos demais entes federativos prevista nesta Lei Complementar;

XVI - elaborar relação de espécies da fauna e da flora ameaçadas de extinçāo no respectivo território;

XVII - autorizar a apanha de espécimes da fauna silvestre, ovos e larvas destinadas à implantação de criadouros e a pesquisa científica; 
XVIII - autorizar o funcionamento de criadouros da fauna silvestre; e

XIX - controlar a produção, a comercialização e o emprego de técnicas, métodos e substâncias que comportem risco para a vida, a qualidade de vida e o meio ambiente.

Art. $8^{\circ}$ Para os fins do art. 5, são ações administrativas dos Municípios, dentre outras:

I - executar e fazer cumprir, no nível municipal, as Políticas Nacional e Estadual de Meio Ambiente;

II - exercer a gestão dos recursos ambientais do âmbito de sua jurisdição;

III - formular, executar e fazer cumprir a Política Municipal de Meio Ambiente;

IV - promover, no município, a integração de programas e açōes de órgāos e entidades da Administração Pública Federal, Estadual e Municipal, relacionados à proteção e à gestão ambiental;

V - articular a cooperação técnica, científica e financeira, em apoio às Políticas Nacional, Estadual e Municipal de Meio Ambiente;

VI - promover o desenvolvimento de estudos e pesquisas direcionados à proteção e à gestão ambiental, divulgando os resultados obtidos;

VII - organizar e manter o Sistema Municipal de Informações sobre Meio Ambiente;

VIII - prestar informações aos Estados e à União para a formação e atualização dos Sistemas Estadual e Nacional de Informações sobre Meio Ambiente;

IX - elaborar o zoneamento ambiental de âmbito municipal, em conformidade com o zoneamento nacional e estadual;

$\mathrm{X}$ - definir espaços territoriais e seus componentes a serem especialmente protegidos;

XI - promover e orientar a educação ambiental em todos os níveis de ensino e a conscientização pública para a proteção do meio ambiente;

XII - exercer o controle e a fiscalização das atividades e empreendimentos cuja competência para licenciar, ambientalmente, for cometida ao Município;

XIII - exercer o controle e a fiscalização ambiental das atividades e empreendimentos cuja competência para autorizar, ambientalmente, for cometida ao Município;

XIV - promover o licenciamento ambiental das atividades ou empreendimentos, a saber:

a) que causem ou possam causar impacto ambiental direto de âmbito local; e 
b) localizados em unidades de conservação do Município, exceto em Áreas de Proteção Ambiental - APAs, onde deverá ser observado o critério do impacto ambiental direto das atividades ou empreendimentos;

XV - autorizar a supressão de vegetação em unidades de conservação do Município e em áreas efetivamente urbanizadas, observadas as atribuições dos demais entes federativos prevista nesta Lei Complementar;

XVI - autorizar o corte seletivo de árvores para utilização no próprio município, observadas as atribuições dos demais entes federativos prevista nesta Lei Complementar; e

XVII - controlar a produção, a comercialização e o emprego de técnicas, métodos e substâncias que comportem risco para a vida, a qualidade de vida e o meio ambiente.

Art. 9 A construção, instalação, operação e ampliação de estabelecimentos e atividades utilizadoras de recursos ambientais, considerados efetiva e potencialmente poluidores, bem como os capazes, sob qualquer forma, de causar degradação ambiental dependerão de prévias licenças do ente federativo responsável por promover o licenciamento ambiental, nos termos desta Lei Complementar.

$\$ 1^{9}$ Os demais entes federativos interessados poderão se manifestar, de maneira não vinculante, no procedimento de licenciamento ambiental.

$\$ 2^{\circ}$ A supressão de vegetação decorrente de licenciamentos ambientais será autorizada pelo ente federativo licenciador.

Art. 10. Para os efeitos desta Lei, considera-se:

I - impacto ambiental direto de âmbito nacional ou regional: aquele que afete diretamente, no todo ou em parte, o território de dois ou mais Estados Federados ou cujos impactos ambientais significativos diretos ultrapassem os limites territoriais do País;

II - impacto ambiental direto de âmbito estadual: aquele que afete diretamente, no todo ou em parte, o território de dois ou mais Municípios; e

III - impacto ambiental direto de âmbito local: aquele que afete direta, no todo ou em parte, o território de um município sem ultrapassar o seu limite territorial.

Art. 11. A ação administrativa subsidiária dos entes federativos dar-se-á, em caráter geral, por meio de apoio técnico, científico, administrativo ou financeiro, sem prejuízo de outras formas de cooperação.

Art. 12 As ações administrativas subsidiárias, de que tratam o parágrafo único do art. $3^{\circ}$ desta Lei, nas hipóteses do art. $7^{\circ}$, incisos XIV, XV, XVII e XVIII, e do art. $8^{\circ}$, incisos XIV, XV e XVI, dar-se-á da seguinte forma:

I - inexistindo órgão ambiental no Estado ou no Distrito Federal, a União desempenhará as ações administrativas estaduais ou distritais até a sua criação; e 
II - inexistindo órgão ambiental no Município, o Estado desempenhará as ações administrativas municipais até a sua criação.

Art. 13. Nos casos de iminência ou ocorrência de dano ambiental, o ente federativo que tiver conhecimento do fato deverá agir para evitar ou cessá-lo.

Parágrafo único. O ente que atuou para evitar ou cessar o dano ambiental comunicará imediatamente o ente federativo responsável, para as providências devidas.

Art. 14. Esta Lei Complementar entra em vigor na data de sua publicação. 